\title{
JOURNAL.RU
}

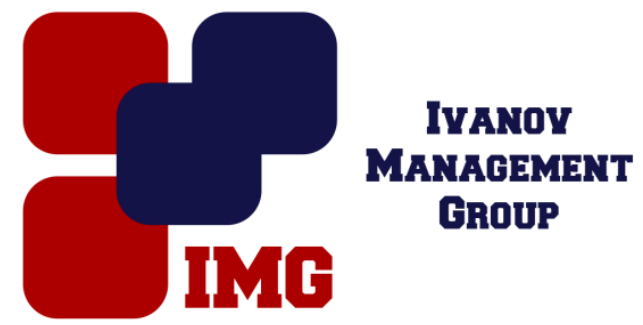

Лукомская А.С., Балаева М.С. Удмуртский государственный университет Ижевск, Россия

doi: 10.18411/1j-30-04-2017-3-14

idsp 000001:1j-30-04-2017-3-14

\section{О привлечении к дисциплинарной ответственности сотрудников ОВД за несоблюдение учетно-регистрационной дисциплины}

\section{Аннотация}

В статье приводится круг нормативно-правовых актов регулирующих отношения по привлечению к дисциплинарной ответственности сотрудников органов внутренних дел за несоблюдение учетно-регистрационно дисциплины, приводятся особенности организации служебных проверок по таким фактам.

Ключевые слова: дисциплинарная ответственность, сотрудники органов внутренних дел, учетно-регистрационная дисциплина, служебная проверка, дисциплинарный проступок

Наиболее точное формирование статистических сведений о преступности в государстве, упорядочивание и строгое соблюдение учетно-регистрационной дисциплины в органах внутренних дел, позволят создать предпосылки для позитивного изменения криминальной обстановки в государстве.

Проблема несоблюдения учетно-регистрационной дисциплины и норм УПК РФ остается актуальной с принятия совместного приказа Генпрокуратуры России N 39, МВД России N 1070, МЧС России N 1021, Минюста России N 253, ФСБ России N 780, Минэкономразвития России N 353, ФСКН России N 399 от 29.12.2005 «О едином учете преступлений».

В 2010 году к дисциплинарной ответственности было привлечено 33,6 тыс. сотрудников ОВД, допустивших нарушения в данной сфере, в том числе более 8 тыс. - за незаконный или необоснованный отказ в возбуждении уголовного дела, 11,1 тыс. - за нарушение порядка и сроков рассмотрения сообщений о 
преступлении, а 2,3 тыс. - за незаконное или необоснованное приостановление предварительного следствия (дознания).[1] В 2011-2012 году по результатампроверки полноты проведения ОРМ по установлению без вести пропавших лиц в 32 субъектах РФ прокуратурой выявлено свыше 14 тыс. нарушений законодательства об ОРД. По результатам рассмотрения актов прокурорского реагирования к дисциплинарной ответственности привлечено свыше 1 тыс. сотрудников полиции.[2]

В Директивах МВД России, устанавливающих приоритетные направления деятельности органов внутренних дел, МВД России, неоднократно указывалось на необходимость укрепления учетно-регистрационной дисциплины как основного фактора, определяющего уровень доверия населения к органам правопорядка. Ежегодно по вопросам учетно-регистрационной дисциплины проводится около тысячи координационных совещаний руководителей правоохранительных органов. Любой сотрудник, независимо от занимаемой должности, привлекается к строгой дисциплинарной ответственности вплоть до увольнения из органов внутренних дел и уголовного преследования за установленные факты нарушения учетно-регистрационной дисциплины.[3]

Применение к сотрудникам органов внутренних дел дисциплинарных взысканий урегулировано главой IV Положения о службе в органах внутренних дел РФ, утвержденного Постановлением Верховного Совета РФ от 23 декабря 1992 г. N 4202-1, а также разделом XIII Инструкции о порядке применения Положения о службе в органах внутренних дел РФ, утвержденной Приказом Министра внутренних дел РФ от 14 декабря 1999 г. N 1038.

Постановление ВС РФ от 23 декабря 1992 N 4202-1 «Об утверждении Положения о службе в органах внутренних дел Российской Федерации и текста Присяги сотрудника органов внутренних дел Российской Федерации» определяет, что нарушением сотрудником органов внутренних дел служебной дисциплины признается виновное действие (бездействие), повлекшее за собой нарушение законодательства Российской Федерации, дисциплинарного устава органов внутренних дел Российской Федерации, должностного регламента (должностной инструкции), правил внутреннего распорядка органа внутренних дел (подразделения) либо выразившееся в несоблюдении требований к служебному поведению или в неисполнении (ненадлежащем исполнении) обязательств, предусмотренных контрактом, служебных обязанностей, приказов, распоряжений и указаний прямых начальников и непосредственного начальника, если за указанное действие (бездействие) законодательством 
Российской Федерации не установлена административная или уголовная ответственность.

Согласно ч. 3 ст. 21 Федерального закона от 30 ноября 2011 N 342-Ф3 (ред. от 03 июля 2016) «О службе в органах внутренних дел Российской Федерации и внесении изменений в отдельные законодательные акты Российской Федерации» гражданин, поступающий на службу в органы внутренних дел, и сотрудник органов внутренних дел при заключении контракта обязуются выполнять служебные обязанности в соответствии с должностным регламентом (должностной инструкцией) и соблюдать ограничения и запреты, связанные со службой в органах внутренних дел, а также внутренний служебный распорядок федерального органа исполнительной власти в сфере внутренних дел, его территориального органа, подразделения.

Общие требования к служебному поведению для гражданских служащих регламентированы в ст. 18 Федерального закона от 27 июля 2004 N 79-Ф3 (ред. от 03 июля 2016, с изм. от 19 декабря 2016) «О государственной гражданской службе Российской Федерации», согласно которым гражданский служащий обязан исполнять должностные обязанности добросовестно, на высоком профессиональном уровне.

В целях повышения эффективности прокурорского надзора и ведомственного контроля за соблюдением права граждан на доступ к правосудию, а также сокращения сроков проверок сообщений о преступлениях и предварительного расследования Прокуратурой РФ рекомендовано при вынесении уполномоченными подразделениями незаконных или необоснованных постановлений по результатам рассмотрения сообщений о преступлениях и расследования уголовных дел, несоблюдении учетнорегистрационной дисциплины принимать соответствующие меры реагирования.

В соответствии с ч. 1 ст. 50 Федерального закона № 342-Ф3 от 30 ноября 2011 года(ред. от 03.07.2016) «О службе в органах внутренних дел Российской Федерации и внесении изменений в отдельные законодательные акты Российской Федерации» на сотрудника органов внутренних дел в случае нарушения им служебной дисциплины могут налагаться следующие дисциплинарные взыскания: замечание; выговор; строгий выговор; предупреждение о неполном служебном соответствии; перевод на нижестоящую должность в органах внутренних дел; увольнение со службы в органах внутренних дел. 
Согласно Приказа МВД России от 26.03.2013 N 161 «Об утверждении Порядка проведения служебной проверки в органах, организациях и подразделениях Министерства внутренних дел Российской Федерации» основанием для проведения служебной проверки является необходимость выявления причин, характера и обстоятельств совершенного сотрудником дисциплинарного проступка.

При этом, полагаем важно, что при проведении проверки по факту нарушения учетно-регистрационной дисциплины, применительно к различным направлениям служебной деятельности, необходимо установление наличия достаточных данных, позволяющих сделать вывод о нарушении сотрудником правил приема и регистрации (в том числе в электронной форме) заявлений и сообщений о преступлениях, о происшествиях; своевременное принятие по ним мер, предусмотренных законодательством Российской Федерации, в том числе правильности ведения КУСП (осуществление контроля за его ведением), а также проведением проверок сообщений о преступлениях до истечения предусмотрено гост. 144 УПК РФ срока.

При этом, если речь идет о руководителе подразделения, такие нарушения могут также выражаться в не обеспечении ежедневного контроля за соблюдением сроков разрешения заявлений и сообщений о преступлениях, административных происшествиях, а также правильностью ведения КУСП, упущений, допущенных по ненадлежащей организации работы следственных подразделений и др. Необходимо устанавливать качество и конкретность ежедневных указаний о проведении конкретных проверочных мероприятий по материалам проверок, их соответствие действительности, фактов нарушений сроков направления материалов с принятыми решениями об отказе в возбуждении уголовного дела. Полученные сведения сопоставлять с исследованием статистических данных, местом в рейтинговой таблице органа внутренних дел. Также, необходимо учитывать результат эффективности работы, наличие или отсутствие поступающих из органов прокуратур представлений по фактам нарушения учетно-регистрационной дисциплины, наличие других нарушений, выявлять формализм в работе руководящего состава.

Предлагается, с целью защиты прав сотрудников органов внутренних дел, детально и четко регламентировать порядок и организацию проведения служебных проверок по фактам нарушений учетно-регистрационной дисциплины, с выделением признаков состава дисциплинарного 
правонарушения, детализацией их элементов, что возможно с разработкой конкретного Приказана уровне МВД России.

1. Интервью с начальником ДСБ МВД России Ю. Драгунцовым // РИА «Новости». 2011. 15 февраля.

2. Скосарев В.В. О состоянии законности при осуществлении органами внутренних дел розыска лиц, пропавших без вести // Прокурор. 2013. N 1. С. 73 - 80.

3. Трунцевский Ю.В. Состояние и тенденции преступности в Российской Федерации и прогнозы ее развития // Российская юстиция. 2016. N 8. С. 29 - 31. 